\title{
淡路公園島づくり 一淡路花博の果たす役割一
}

\section{The Realization of Awaji Garden Islands \\ - The Role of The International Gardening and Landscaping Exhibition JAPAN FLORA 2000 -}

石原憲一郎*

Kenichiro ISHIHARA

\section{1.はじめに}

21世紀を間近に控え, 政治, 経済, 教育, 産業, 生活,

環境，福祉，都市あらゆる諸相において，これまでと異な る対応を求められている。

特に, 地球環境における環境問題の顕在化は, 人類の生 存基盤にまで係わる大きな問題にまで発展しつつあり, 現 存する我々の生き方, 暮らし方そのものが問われており, 今こそ国家，地域を超えた英知が求められている。

また，経済的豊かさを背景に，ますます高度化する情報 化社会への移行の中，国民の多くが自然環境や景観に配慮 した美しい生活環境を求めるのは当然のことである。

このように社会潮流の変化が大きく進む中, 平成10年 3 月，21世紀における日本の国土づくりの長期的指針である 全国総合開発計画「21世紀の国土のグランドデザイン」が 策定された。特に計画の冒頭に掲げられた国土づくりの理 念では, 歴史之風土の特性に根ざした新し文化と生活様式 を持つ人々が住む美しい国土，庭園の島とも言うべき世界 に誇りうる日本列島を現出させ, 地球時代に生きる我が国 のアイデンティティを確立することとしている。

兵庫県では, 日本の縮図といわれる多様な自然環境を背 景に「さわやかな県土づくり」を進めており，地域固有の 歴史や文化のなか，県民にとって快適で美しい生活環境の 実現に努力してきたところであるが，今後，「庭園の島」 づくりに呼応し，様々な施策を実施していくことが求めら れる。

なかでも, 淡路島は, 国生み神話の島として, 古い歴史 之伝統, 文化を持ち, 世界で最む美しい風景の一つとされ る瀬戸内海の東部に位置し，温暖な気候とすぐれた自然環 境に恵まれた美しい島として，これまでも「淡路公園島づ くり」を施策として掲げ，国の政策に先行し総合的かつ計 画的に地域づくりを進めてきた。

平成12年 3 月から開催された国際園芸・造園博覧会ジャ パンフローラ2000 (通称: 淡路花博。以下「淡路花博」) は，明石海峡大橋の開通など外部環境が大きく変化した淡
路島にとって淡路公園島づくりの第二ステージの起爆剤と して，その意義は極めて大きい。

\section{2. 淡路花博}

\section{(1)経緯}

淡路花博は, 平成 3 年, 21 世紀の文明を見つめ, 明石海 峡大橋の開通を記念し, 淡路島をはじめ大阪湾べイエリア の地域振興を誘発する目的で構想された「コミュニケーショ ン文明の祭典」を原型とする。

その後, 人と自然のコミュニケーションを媒介する代表 として花と緑が取り上げられ，祭典の具体的な形として国 際園芸・造園博覧会を平成10年に淡路島で開催することで 誘致することとなった。

建設省都市局公園緑地課や日本造園建設業協会の多大な 支援のもと, 平成 5 年AIPH（国際造園家協会）の承認を 受け正式に開催が決定した。平成 6 年日本造園学会をはじ めとする学術団体や学識者の参加のもと, 開催理念や基本 構想が決定され順調に進んでいたが，平成 7 年 1 月 17 日悪 夢の上うな阪神・淡路大震災が起こり, 当面, 復旧・復興 に全力を挙げることから，同年 4 月，平成12年に開催を延 期した。当然，延期を決める過程で，被災者としての県民 感情を尊重し開催中止という意見も出たが，被災者及び被 災地の復旧・復興を出来るだけ早期に行い, 博覧会の開催 により多くの方に来て頂き，復興後の兵庫，神戸そして淡 路島をご覧頂く之共に，物心両面の膨大な支援に感謝する ことの重要性から貝原知事が博覧会開催を決断されたので ある。

博覧会は, 時代背景の変化や価值観の多様化により開催 意義, 役割屯大きく変わってきているが, 淡路花博は, 本 来的な造園・園芸技術の向上, 産業の振興, さらに地域活 性化に加え, 阪神・淡路大震災の教訓加ら得た花之緑のま ちづくりの提案, 土砂採取地の自然回復にみる自然環境の 保全と創造の重要性等を理念としていることが特徴である。

*兵庫県立淡路景観園芸学校 
(2)開催意義

・身近な緑から始まる「人と自然のコミュニケーション」 の望ましいあり方を追求し, 緑豊かな地球環境の保全と 創造に寄与する。

・阪神・淡路大震災の教訓に学び, 花, 緑, 水を基調にし た安全で快適な美しいまちづくりを提案するとともに,

21世紀のライフスタイルに応えうる新しい公園緑地を提 案する。

・花と緑を愛し育てることを通じて人々が互いに参加・協 力しあうこころ豊かな地域社会づくりに寄与する。

・これまでの園芸・造園の知識と技術を集大成し, その成 果を展示するとともに新しい技術の提案等を意欲的に行 い, 園芸・造園産業の発展とその国際的な振興を図る。

・阪神・淡路地域の震災復興を内外にアピールするととも に,「国営明石海峡公園」「淡路島国際公園都市」の建設 や「世界に開かれた公園島づくり」を促進して，世界都 市・関西の形成に貢献する。

(3)博覧会の性格

国際園芸家協会 (AIPH) が承認する国際参加のある長 期間の国際園芸博（B類 1 ) と国際園芸博（A類 2 ）の組 み合わせによる国際園芸博覧会 $($ 戍 -1 )。

\begin{tabular}{|c|c|c|c|c|}
\hline \multirow{2}{*}{$\begin{array}{l}\text { 分類 } \\
\text { 項目 }\end{array}$} & \multirow{2}{*}{$\begin{array}{c}\text { 大国際博覧会 } \\
\text { A } 1\end{array}$} & \multirow{2}{*}{$\begin{array}{c}\text { 国際園芸博覧会 } \\
\text { A 2 } 2\end{array}$} & \multicolumn{2}{|c|}{ 国際参加のある園芸博臨会 } \\
\hline & & & 長期 B1 & 短期 B2 \\
\hline $\begin{aligned} \text { 1. 開俟 } \\
\text { 頻度 }\end{aligned}$ & $\begin{array}{l}\cdot \text { 年1 回以下 } \\
\cdot 1 \text { 国につき } \\
10 \text { 年に1回 } \\
\cdot \text { BIE との協議 }\end{array}$ & 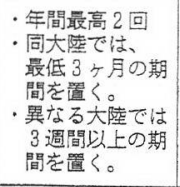 & $\begin{array}{l}\text { ·曆年につき1 回 } \\
\text { 以下 }\end{array}$ & 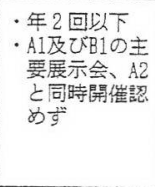 \\
\hline $\begin{array}{l}\text { 2. 開催 } \\
\text { 期間 }\end{array}$ & $\begin{array}{ll}\text { 最低 } & 3 \text { ヶ月 } \\
\text { 最高 } 6 \text { 号 }\end{array}$ & $\begin{array}{l}\text { 最低 } 8 \text { 日聞 } \\
\text { 最高 } 20 \text { 日間 }\end{array}$ & $\begin{array}{ll}\text { 最低 } & 3 \text { r月 } \\
\text { 最高 } & 6 \text { 万月 }\end{array}$ & $\begin{array}{l}\text { 最低 } 8 \text { 日間 } \\
\text { 最高 } 20 \text { 日間 }\end{array}$ \\
\hline 3. 申請 & $\begin{array}{l}\cdot \text { 開催初日の } \\
12 \sim 6 \text { 年前 }\end{array}$ & $\begin{array}{c}\text { ·開催初日の } \\
4 \text { 年前 }\end{array}$ & $\begin{array}{c}\cdot \text { ·笄偳初日の } \\
3 \sim 7 \text { 年前 }\end{array}$ & $\begin{array}{l}\cdot \text { 開催初日の } \\
2 \text { 年前 }\end{array}$ \\
\hline $\begin{array}{l}\text { 4. 特別 } \\
\text { 規定 }\end{array}$ & 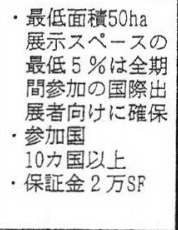 & $\begin{array}{l}\cdot \text { 最低面樻 } 1.5 \mathrm{ha} \\
\text { 占外国参加者 } \\
\text { 向け } \\
27 \mathrm{~m}^{2} \\
\cdot \text { 参加国 } \\
6 \text { 力国以上 } \\
\cdot \text { 保証金 } 1 \text { 万SF }\end{array}$ & $\begin{array}{l}\text { ·最低面樻 } 25 \mathrm{ha} \\
\text { jち外国参加者 } \\
\text { 向け } \\
\text { 3\%炎確保 }\end{array}$ & $\begin{array}{l}\text { ·保酦金 } \\
\text { 2. } 5 \text { 干SF }\end{array}$ \\
\hline
\end{tabular}

淡路花博

\section{図－1 国際博覧会の分類と内容}

(4)入場者目標

入場者については, 花と緑の博覽会として, ゆったりと 花や緑そして数々の庭園や広大なオープンスペースを楽し む，いわば，ヨーロッパ型の園芸博を目指しパビリオン等 構造物を制約したこともあり当初計画していた 1000 万人を 大きく下方修正し500万人とした。

(5)運営主体

国際博覧会として位置づけられた淡路花博は, 単に兵庫 県や関西圏と言った一地域のいわゆる地方博ではなく，日
本を代表する博覧会としての性格を付与する必要がある。 このため, 建設省, 農林水産省の特別協力のもと, 経団連 をはじめとする全国規模の団体や学識者により構成された 国際園芸・造園博覧会ジャパンフローラ2000日本委員会を 主催者の一員とし兵庫県の外郭団体である(財夢の架け橋記 念事業協会との共催とした。

(6)会期及び開催地

- 会期

会期は西暦2000年 3 月18日から同年 9 月 17 日までの 184 日間である。

- 開催地

兵庫県淡路島全島を会場と位置づけ, 淡路島に渡ればそ こから博覧会場に出会うという考えを基本としている。主 たる会場は，かつて大阪湾の住宅・産業用地や関西国際空 港用地等の人工島に必要となった埋め立て用土砂の採取跡 地で, 現在, 国営明石海峡公園（淡路地区), 県立淡路島 公園, 淡路夢舞台等により構成された淡路島国際公園都市 の計画地である。

淡路花博は，これまでの博覧会と違い，会場の主たる区 域を公園整備途上にある国営明石海峡公園を一時借用して 利用しており, その意味では博覧会後の跡地利用計画につ いて心配する必要がないのが特徴である。

(7)会場計画

会場計画の策定にあたっては，建築，造園，園芸，照明 の分野からプロデューサーを選定し，それぞれの立場から 会場計画の策定に必要な指導を頂いた。

会場計画

・明石海峡大橋など，周囲の都市景観・文化景観をより高 める会場とする。

また, 会場内はもとより, 遠く海や空からの景観につい ても重視し, 公園島淡路にふさわしい景観思想を持った 会場とする。

・エコロジカルな視点から, 自然の循環を尊重し, クリー ンェネルギーを使用するなど, 真に環境にやさしい会場

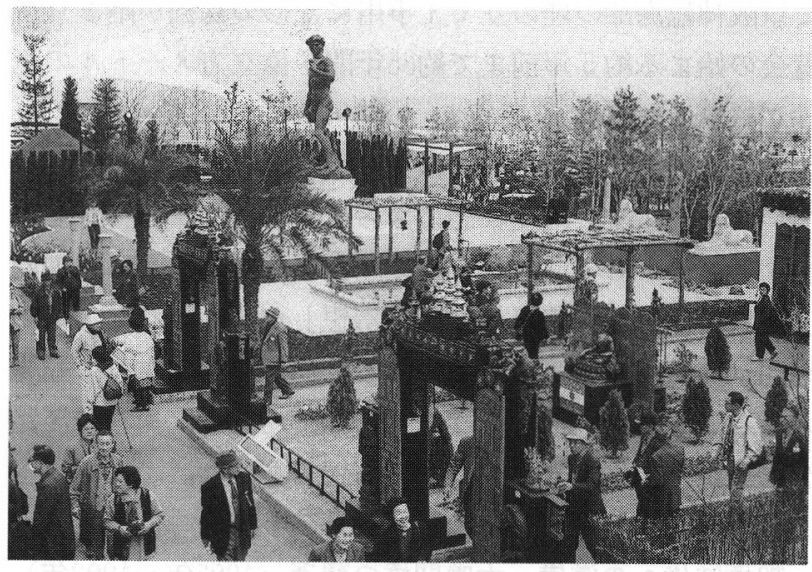

写真ー 1 ジャパンフローラの会場風景 
とする。このため，会場の一部は，ビオトープ的な空間 とする。

- 環境緑化と自然回復に関する細心の技術や可能性を追求 しながら，会場を快適な環境創造への先駆的実践の場と する。植栽・修景もこうした観点に立った展示とする。

・「ノーマライゼーション」の視点で, 幼児, 高㱓者, 障 害者をはじめ全ての来場者に優しい会場とする。

\section{3．淡路公園島づくりと淡路花博}

(1)淡路公園島の歩み

淡路島は，江戸期に農地を積極的に開くことにより豊か な島となり，江戸末期に人口は，現在とほぼ同じ約 $16 万 人$ に增加する。阿波藩の城代家老が常駐し，自立的な経済圈 を形成しつつあった。また, 明治時代は, 酪農, 果物栽培, 紡績，製紙，製陶，金融など近代産業の担い手が数多く輩 出し，大正時代は鉄道が出来るなど大いに䀼った。しかし， 中央集権体制のなかで, 淡路島はモノ, 人, 情報全て中央 に提供するだけの地域となり急速に活力が低下した。

戦後,さらに人口流出はとどまることを知らず日本の多 くの「地方」と同じような運命をたどるが，大都市圈に近 いという立地条件や架橋が淡路島を变えていくこととなる。

淡路島を取り巻く近年の社会環境の変化とそれに対応し た地域づくりの歴史は，大鳴門橋の開通，明石海峡大橋の

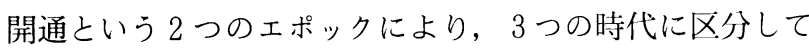
考えることができるので概観してみよう。

一島の時代・花とミルクとオレンジの島（1984年以前）島の時代としての淡路島は, 京阪神大都市地域に近い距 離にありながら島と本上を結ぶ交通手段は全て海上交通に 限定されていたため「花（花卉産業）とミルク（酪農）上 オレンジ（果樹栽培）の島」と呼ばれてきたように，農林 水産業を中心に観光を加えた比較的, 経済自立性の高い地 域として存在し, 開発圧力もそれほどではなかった。

しかし，1996年代に入り淡路花博の会場である灘山地区 で京阪神臨海部の埋め立て工事用に土砂の採掘が始まり博 覧会の始まる約 5 年前まで約 35 年間 1 億立方メートルの土 砂が採取された。

一方，1962年淡路地域の振興を図るため，既に提唱され ていた全島産業公園化構想にさらに具体的なイメージを付 加するむのとして, 産業, 観光開発と島内の生活環境の向 上を目指した「淡路島植物園化構想」が策定された。この 構想は亜熱帯植物等の導入による全島の緑化により, 観光 地としてのグレードアップを目指したもので, 現在の淡路 公園島構想の下敷きともいえる構想であった。

一架橋時代への準備・大鳴門橋の開通（1985年～1992年） 淡路島と四国をつなぐ大鳴門橋が開通した1985年には,
その10年後に明石海峡大橋を完成させる事業屯決定された。 この年, 大鳴門橋の開通を記念して「くにうみの祭典」が 開催され, 主として淡路島中南部に, 淡路ファームパーク, おのころ愛ランド等数多くの公園やレクリエーション施設 が整備され，同年策定された兵庫県の総合計画である兵庫 2001年計画に扔いて，淡路島の将来方向を「世界に開かれ た公園島」とした。

淡路島民は, くにうみの祭典に来訪する多くの観光客の ため，花と緑の美しい公園島づくりを目指し，花之緑のま ちづくり推進グループの結成及び緑花活動や全島一斉掃除 など，島ぐるみでグリーン・クリーン作戦を展開した。

現在, 花と緑のまちづくり推進グループは, 全島で約 560 グループ，構成人員約 7100 人に及び，淡路島は県下で 最も活発な活動を行っている先進的な地域であるが，その 始まりは大鳴門橋の開通にあわせた公園島づくりである。

博覧会等イベントの効果が顕著に現れた例である。

しかし，橋の開通はそれまでの秪やかな島の時代から他地 域からの交通アクセスや様々な開発圧力がかかるというこ とを意味していた。

島の時代から続いていた土砂採取についても，リゾート 開発等様々な理由によりさらに対象地が拡大され，淡路島 の自然環境や生活環境に大きな影響を与えることになった。 欧米では鉱山等の採掘に際して予防医学的見地からRECL AMATION（矯正，荒廃地の再生）という考元方で，地 形改变前に当該開発地の跡地利用計画，修復整備計画等を 策定し，採掘後美しい保養地や公園に生まれ变わっている。

淡路花博の対象地である灘山についても土砂採取前には ゴルフ場としての跡地利用計画及び緑化計画が提出されて いたが, 社会情勢の変化等により1993年に淡路島国際公園 都市構想が策定され，自然回復や公園化が実現した。淡路 花博を契機に, 今後, 淡路島各地で現出する土砂採取地の 跡地利用計画及び自然回復計画について負担のルール等仕 組みを構築するとともに自然回復技術の開発を急ぐ必要が ある。

1988年, 民間活力を活用し, 豊かな自然と調和した国際 性のある海洋性リゾートを目指す「淡路島リゾート構想」 を策定し, 総合保養地域整備法に基づく対象地として, 全 国で 4 番目に国から承認を受けた。

北淡路地域の都市農村交流拋点「淡路フルーツガーデン 構想」等多くの魅力的な民間活力期待のプロジェクトが計 画された。

兵庫県では, 民間開発に先立ち1989年淡路島のランドス ケープ形成のあり方を検討するため「淡路島ランドスケー プ広域計画」を策定し，その実践モデル計画を策定した。 また，秩序あるリゾート開発・土地利用を誘導するため 「兵庫県リゾート整備基本構想」を同年策定するとともに, 民間開発に対し一定の規制をかけ，自然環境の保全，景観 
形成・緑化の義務等を定めた「淡路地域の良好な地域環境 の形成に関する条例」を同年公布した。しかし，経済環境 の激変に伴う民間企業の開発意欲の減退により, 多くの事 業が行き詰まり，事業や計画の見直しが必要になるととも に, 淡路島地域振興のため公共性の高い事業が求められた。 1992年，従前の「淡路島リゾート構想」を抜本的に見直 し, 計画内容を開発型から環境保全型とし, 民間プロジェ クトの削減や公共的事業の追加等を盛り込んだ「淡路公園 島構想」を策定した。

\section{一架橋時代・明石海峡大橋の開通，そして淡路花博へ（19 93年 ）}

1993年以降，我が国の経済成長のスローダウンにより， 急激な開発圧力は弱まったが，兵庫県は明石海峡大橋の効 果を最大限高めるため淡路公園島構想の具体化をより進め, 淡路島国際公園都市の整備着手, 県立淡路島公園ハイウェ イオアシスの整備, 各種既存施設のリニューアル等官民挙 げて積極的に行った。この結果平成10年度観光客総入り込 み数は，2298万人と，刘前年度比 $317.6 \%$ となった。

また, 淡路島の多様な地域の生態系とそれを支える地域 環境の保全・創造に取り組む「兵庫ビオトーププラン・淡 路地域ビオトープ地図」を策定した。この生物空間計画, 生物空間地図の作成は，ドイッの自治体において本格的に 策定され，土地利用の変更等にと屯なう生物層に与える影 響を最小限に押さえ，かつ生物層の復元を図る上で大きな 役割を果たしているが，我が国において本格的に調查され たのは淡路島が始めてである。こうした貴重な調查成果を 継続的に生かしていく仕組みが未整備であることが残念で ある。

我が国の多くの自治体で有用な調査が行われているが, 調査成果を生かす仕組みづくりの整備が脆弱であることが 問題である。

一方, 淡路景観園芸学校の開設準備屯始まり, 当初, 淡 路花博の開催之あわせ開校する予定であったが，淡路花博

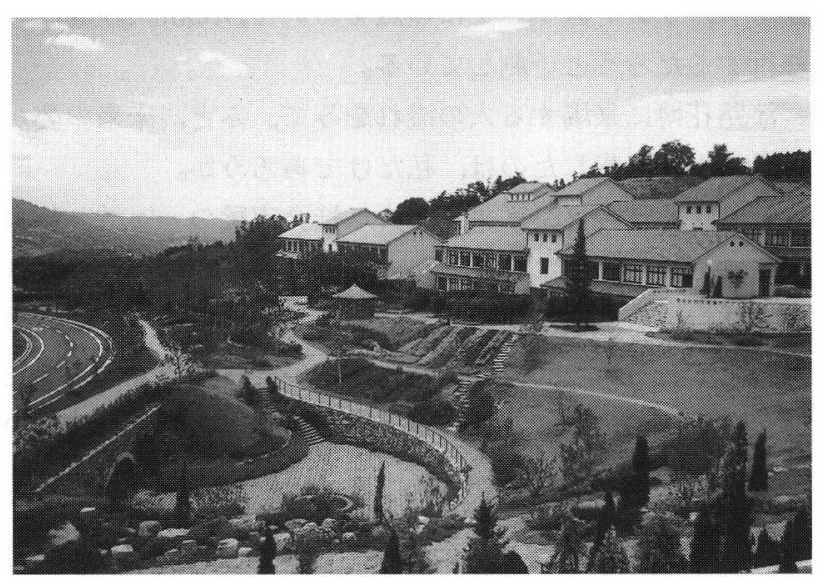

写真ー 2 淡路景観園芸学校キャンパス風景
の準備屯含めて参画するため博覧会開催の 1 年前に開校し た。

また, 淡路島民と共に, 淡路公園島構想のうち, 花や緑 のまちづくり,ゴミの散乱防止, 広告景観の整序を一体と して取り組む必要性と計画を明示したあわじ花回廊構想を 策定した。

1998年，あわじ花回廊構想の花拠点の一つとして，あわ じ花さじきを整備するとともに, 近接地の高台に淡路景観 園芸学校を淡路花博の開催に一年先行し開設した。 そして，2000年 3 月淡路花博が華やかに開催され県内外か ら予想を大きく超える来訪者を迎えている。

(2)淡路景観園芸学校と淡路花博

淡路島の公園島づくりが淡路花博以前から着実に進めら れてきた経緯は前述のとうりであるが，今後21世紀に向け て，いわば，淡路公園島づくりの第二ステージに入るこの 時期に淡路島で行われた淡路花博は大きな意味を持つ。

また, 今回の淡路花博の最大の成果は, 淡路景観園芸学 校という今後の淡路公園島づくりに必要な知的拠点, 交流 拠点，人材育成拠点という大きなシンクタンクを生み出し たことであろう。

淡路景観園芸学校は, 人材育成機能, 生涯学習機能, 調 査研究機能, 情報発信機能, 産業振興機能の 5 つの機能を 持ち，実技・実践主体の教育内容を有する全国でも全く新 しいタイプの教育研究機関である。

教育のフィールドは，キャンパスの中に留まらず淡路島 全島を対象としており, 島内各自治体之の共同研究や教員 によるアウトリーチプログラム (出前講義) 等を通じて淡 路島に根ざした学校として位置づけ, さらに淡路島を通じ て兵庫県内，日本，そしてアジアに貢献できる教育研究機 関としての方向性を打ち出している。

現在, 淡路景観園芸学校の教員, 学生は淡路花博の出展計 画, 運営等様々な形で関係し大きな学習効果を上げている。 今後, 会期末まで残された期間, 淡路花博の成果を記録 としてまとめ, 後世に引き継いでいくことが極めて重要で あるが，淡路景観園芸学校屯その役割の一部を担っていく こととしている。

(3)淡路公園島づくりと淡路花博

淡路公園島構想は, 淡路島全島において, 豊かな緑, 美 しい景観, 伝統ある歴史之文化, 特色ある地場産業等の特 性に磨きをかけ，自然環境と調和した，アメニティ豊かな 生活空間の形成と世界に開かれた䀼わいのある多彩な交流 空間の形成を目指している。

この構想においては,

-土砂採取跡地の緑の復元等自然環境の保全と創造

- 淡路島らしい景観の保全, 屋外広告物の整序, 植樹・植 栽等優れた地域景観の形成

・淡路固有の文化の醸成や人々を暖温かく受け入れる心の 


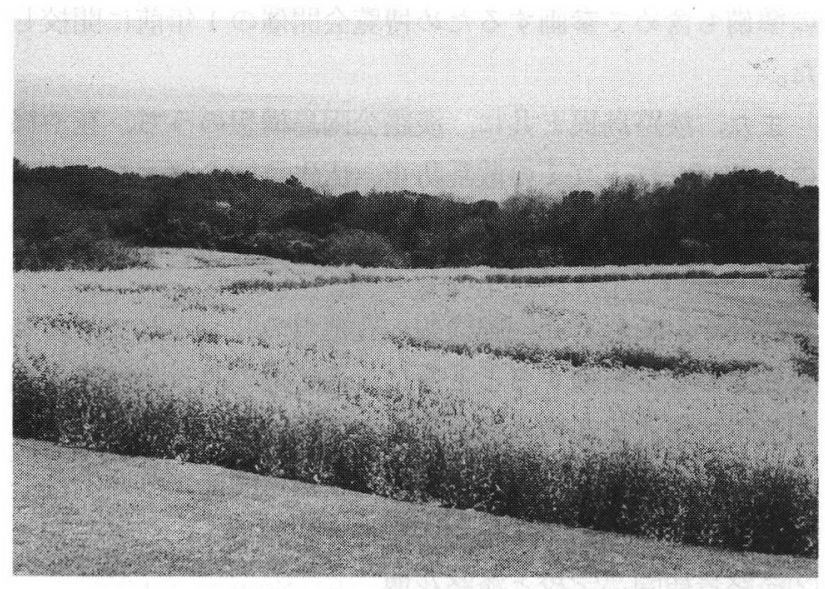

写真ー 3 あわじ花さじき

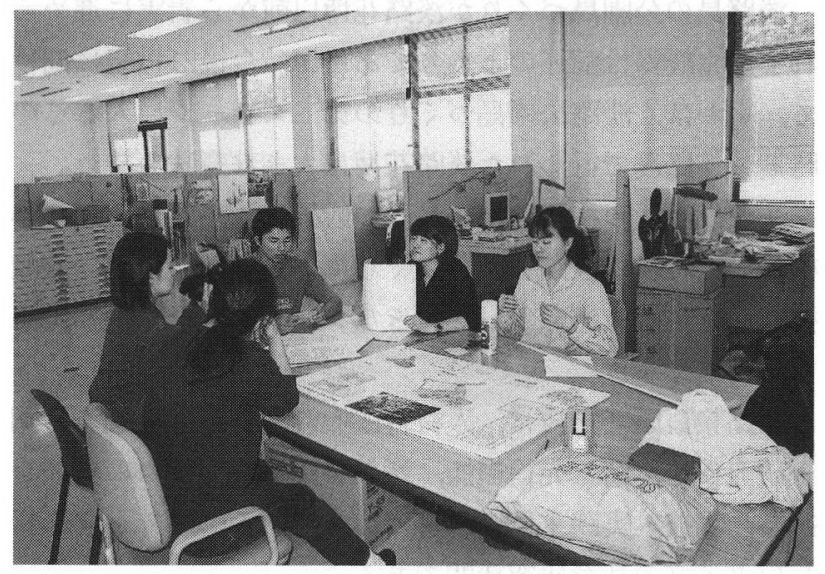

写真－４デザイン実習棟スタジオにおける 学生の自習風景

涵養等地域のホスピタリティの高揚

・観光, レクリエーション事業の展開や特産加工品の開発, 新産業の導入・育成等, 地域産業の活性化

等をその具体的な推進方策としている。

淡路花博は, 淡路公園島構想を先導するプロジェクトと して位置づけているが，淡路花博の成果をより効果的に受 け止めるため淡路花博に先立ち平成 8 年, 自治会, 婦人会, 市町等淡路島の関係団体により構成されるあわじ花回廊構 想推進会議によりあわじ花回廊構想を策定した。

あわじ花回廊構想は, 美しい広告景観の形成や, ゴミの 散乱防止等と有機的連携を図りながら, 淡路地域の潜在力 を「花」に結集し，「花」を通じた新しいライフスタイル の創造を図ることとし，(1)「家庭や地域社会からの緑花」 から「島全体からの緑花」(2)「行政」と「住民の知恵之実 践の連係プレー」(3)量的展開の目標は「風景レベル」, 質 的展開の目標は「感動レベル」, あわせて「淡路らしさの 創出」(4)「花が美しく見える背景づくり」のための基盤整 備(5)緑花活動の楽しみを基本に「自発的参加」と「持続性」 (6)「観光産業・農業等地場産業の振興」と「地域の活性化」 の 6 つの連携プレーで展開することを基本方針としている。 また, 淡路花博を契機に, 美しい景観を生む新しい花の
文化を興し，「震災の島」から「花の島」へ変わることを 宣言した淡路公園島憲章を制定したり, 淡路島 1 市 10 町が 一斉にゴミのポイ捨てや飼い犬のふんの放置を禁止する 「ポイ捨てをなくす美しい島づくり条例」を公布する画期 的な取り組みや，「あてなしの心あふれる淡路」の実現を 図るため, 地域住民の善意により, 来島者等に無償でトイ レを開放する「あわじ花トイレ」制度も確立された。

淡路花博の開催に先立ち淡路公園島づくりに必要な様々 な仕組みが創られたことは, 淡路島民の見識によるもので, 淡路島の地域づくりを進めていく上で大きな意味があった。 さらに, 博覧会の運営に淡路島の多くの県民が参加するこ とにより素晴らしい庭園や出展, 国際交流を通じて淡路公 園島づくりという地域づくりの方向がより確かなむのとな り, 21世紀の淡路島が, あわじ花回廊構想の基本理念とし て掲げられた「世界都市・関西の庭＝花の公園島」になる ことは決して夢ではないであろう。

\section{4. おわりに}

淡路花博が開幕して 7 月31日で 136 日が経過した。開幕 以来入場者数は順調に推移しており, 当初の入場者予測の 500 万人に対し，すでに 7 月 16 日には，500万人を突破した。 会期末の 9 月17日まで, 残すところ48日であるが梅雨, 夏の暑さ等の条件む含め全期間を通じて約 700 万人の来場 者を数えるのではないかと思われる。来場者の好調な要因 は，いろいろあるが会期中好天に恵まれていることや全国 的に競合する大きなイベントが見あたらないこと等のほか, 従来のパビリオン型ではなくヨーロッパの園芸博のような 会場の雄大なランドスケープと多彩な花と緑, 多様な庭園 等, 心の癒しを感じさせてくれる会場づくりが挙げられる。 急速な情報化社会への移行の中, 生物体としての人間が その反動として花や緑そして自然を求めるのは当然の方向 である。

アメリカの未来学者は, 現在の情報社会は今後十数年で, ドリーム, アドベンチャー, スピルチュアリティ, フィー リング，ランドスケープに焦点をおいたDream Societyに 移行するだろうと予測している。

淡路花博に来場する人の流れをみて, ふと, 未来の姿が 見えてきたと感じたのは，私だけであろうか。

なお, 博覧会は, 本来, 壮大な社会実験の一つで, 行政 が日常ではなしえないことへの挑戦, 新技術の提案等大き な意味がある。淡路花博の場合こうした視点がやや弱いの が残念であるが，2004年に開催予定の静岡花博では淡路花 博をさらに進化させて造園界に新しい風を吹かせて欲しい あのである。 